\title{
Kansalaisverkot ja digitaalinen voimistuminen
}

\author{
SIRKKU KOTILAINEN \& MAARIT MÄKINEN
}

\begin{abstract}
Digitaalisten kuilujen eli uuden teknologian käyttöön liittyvien eriarvoisuuksien lisäksi on syytä puhua myös ihmisten eriarvoisesta toimijuudesta tietoyhteiskunnassa. Teknologia sinänsä ei tee ihmisistä syrjäytyneitä tai mukana olevia, vaan sen soveltaminen toimijuutta ja osallisuutta edistävässä tarkoituksessa. Voidaan paremminkin puhua osattomuuden kuiluista ja tietoyhteiskunnan syrjäytyneistä, joille informaatioteknologia voisi tuoda selkeää hyötyä yhteiskunnan jäseninä toimimisen sekä oman hyvinvoinnin kannalta, mutta jotka eivät voi tai osaa sitä hyödyntää.
\end{abstract}

Kansalaisia tietoverkkojen avulla osallistumaan tukevia projekteja ja kokeiluja on maassamme toteutettu lukuisia viimeisten kymmenen vuoden aikana. Nämä projektit voi kiinnittää teknologian yhteiskunnallisen muokkaamisen lähtökohtaan, jolloin oletetaan, että yhteiskunta ja sen toimijat muokkaavat myös teknologiaa (Vehviläinen 2001). Esimerkiksi Pohjois-Karjalassa ja Pirkanmaalla on tavoiteltu asukkaiden omaa tietoyhteiskuntamallia kansalaislähtöisellä verkkoviestinnällä eli kansalaisverkoilla. Näissä tavoitteina ovat olleet yhtä lailla yhteisöjen ja alueiden kehittäminen kuin kansalaisten osallistumismahdollisuuksien lisääminen (Sirkkunen 2004; Ridell 2002).

Hankkeiden arvioinneissa ovat tulleet esiin monet rajoitteet kehitykselle ja se, että toimijuus tietoyhteiskunnassa rakentuu arjen käytäntöjen, yhteisöjen ja verkostojen kudelmassa monin tavoin. Yksilöiden ja yhteisöjen vahvistumisen tukena toimivat muun muassa vertaisverkot, ja oma aktiivisuus uusintaa positiivista kehitystä. Kehitys saattaa myös estyä, mikäli esimerkiksi näitä verkostoja ei ole tai ne eivät toimi. Tässä artikkelissa keskitymme vahvistumisen prosesseihin ja pohdimme kansalaislähtöisten verkkoyhteisöjen kehittymisen edellytyksiä. Olemme kumpikin työskennelleet toimintatutkijoina Tampereella ja Oulussa toteutetussa monivuotisessa tutkimus- ja kehitysprojektissa, jota käytämme pääosin esimerkkinämme.
Artikkeli kiinnittyy mediatutkimuksen näkökulmaan. Tarkastelemme siis tietoverkoissa rakentuvia mahdollisuuksia osallistumiselle kansalaiskulttuuria vahvistavana tekijänä. Ajatuksena on, että Internet voisi avata kentän dialogiselle, osallistuvalle kulttuurille ja poliittiselle toiminnalle vastakohtana institutionaaliselle vallalle ja päätöksille. Toisaalta taustalla on näkemys osallistumisesta oppimisen prosessina. TarkasteIun välineenä käytämme digitaalista voimistumista kuvaavaa mallia, jolla voidaan havainnollistaa kansalaisverkkohankkeissa tapahtuneita osallisuuteen ja toimijuuteen liittyviä muutoksia (Mäkinen 2006).

Voimistuminen käsitetään tässä mahdollisuuksia luovaksi vahvistumiseksi ja kompetenssin lisääntymiseksi, jolloin kansalaisen tai koko yhteisön edellytykset osallistuvana ja omaa elämäänsä hallitsevana tietoyhteiskunnan jäsenenä paranevat (Zimmerman 1995). Digitaalinen voimistuminen puolestaan on prosessi, jossa digitaalisia välineitä kuten uutta viestintäteknologiaa sovelletaan voimistumiskehityksen tukena.

Digitaalinen toimijuus voi toteutua monella tavoin, sillä toimintatavat ja tavoiteltavat päämäärät ovat kontekstiriippuvaisia. Olennaista on yksilön mahdollisuus ja kompetenssi osallistua tietoyhteiskuntaan täysivaltaisen subjektin roolissa. Kansalaisten osallistuminen ja vaikuttaminen merkitsevät aktiivista osallisuutta yhteisistä asioista päättämiseen, mutta yhtä hyvin myös 
aktiivista osallisuutta oman elämän kontrollointiin, vapautta valita ja toimia yhteiskunnassa sekä osallisuutta tietoon, oppimiseen ja yleiseen hyvinvointiin. Näkökulmamme on siis sosiokulttuurinen eikä kiinnity yksin poliittiseen kansalaisuuteen.

\section{Digitaaliset kuilut pysyviä?}

Vuosituhannen vaihteessa Denis McQuail (2000) totesi, ettei digitaalisen teknologian ja verkottumisen kehitys ole vielä radikaalisti muuttanut kansalaisyhteiskuntaa, esimerkiksi politiikan tekemisen tapoja tai kaventanut sosiaalisia ja tiedollisia kuiluja. Edelleen tutkimuksissa raportoidaan esimerkiksi kasvavista digitaalisista ja sosioekonomisista kuiluista ja tietoverkon käyttöönoton pulmista hallitusten aktivoivista toimista huolimatta (esim. Räsänen 2005; Olsson, Sandström \& Dahlgren 2003; Sirkkunen \& Kotilainen 2004).

Pekka Räsänen $(2005,23,32)$ pitää näitä kehittyneitä kuiluja osin pysyvinä, koska teknologian käyttö vaatii vastaavanlaisia taitoja ja kompetensseja kuin perinteinen lukutaitokin. Hän luokittelee kuitenkin nuoret viestintäteknologian varhaisiksi omaksujiksi (early adapters) yhdessä korkean koulutuksen ja hyvän sosioekonomisen aseman omaavien aikuisten kanssa. Sonia Livingstone ja Magdalena Bober (2005) ovat kuitenkin havainneet nuortenkin keskuudessa sosiaaliset erot, jotka ovat siirtyneet verkkoon pääsystä tietoverkkojen käytön laatuun: esimerkiksi käytettävissä olevaan aikaan verkossa, digitaalisiin taitoihin ja näiden myötä erilaisiin online- ja osallistumisen aktiviteetteihin. Tähän digitaalisen syrjäytymisen ja osattomuuden laadun muutokseen ovat kiinnittäneet huomiota myös aikuisten kohdalla esimerkiksi ruotsalaistutkijat Tobias Olsson, Håkan Sandström ja Peter Dahlgren (2003).

"Julkisuutta on nykyään enemmän kuin koskaan aiemmin, mutta kuilu kansalaisten ja vallanpitäjien välillä näyttää vain kasvavan. Miten tätä voidaan selittää?", kysyy Hannu Nieminen (2004). Hän kiinnittää pohdintansa erilaisiin sukupolvikokemuksiin entisessä yksisuuntaista joukkoviestintää korostaneessa yhteiskunnassa ja nykyisessä mediayhteiskunnassa, joka korostaa vuorovaikutteista mediaa. Niemisen mukaan aikuisten käsitykset kansalaisvaikuttamisestakin perustuvat menneen joukkoviestintäyhteiskun- nan vaiheeseen, jolloin vaikuttamisen tavoiksi määrittyivät esimerkiksi äänestäminen, yhdistystoiminta, valitukset viranomaisille ja yleisönosastokirjoitukset. Toisaalta aikuisetkin ovat ottaneet tietoverkkoa haltuunsa esimerkiksi osallistumalla kansalaisadresseihin ja boikotteihin verkossa kuten vaikkapa euroviisuvoittaja Lordin maskittoman kuvan julkistamista koskeneessa mediajupakassakeväällä 2006. Huomionarvoista on se, että nämä aktivistitoimet kohdistuivat juuri mediaan kuten aikaisemmin samana keväänä, kun vanhemmat vaativat lapsiasiamiehen välityksellä iltapäivälehtien lööppejä siistimmiksi lasten silmille (esim. Helsingin Sanomat 4.6.2006)

Digitaalisten kuilujen eli uuden teknologian käyttöön liittyvien eriarvoisuuksien lisäksi voisi olla hyödyllistä pu-

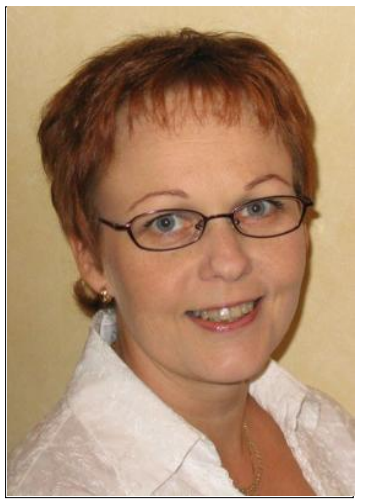

Sirkku Kotilainen

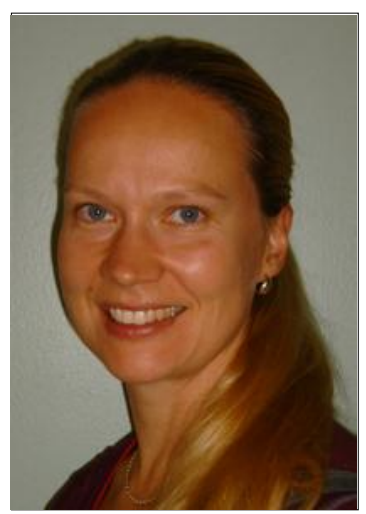

Maarit Mäkinen hua myös ihmisten eriarvoisesta toimijuudesta tietoyhteiskunnassa. Teknologia sinänsä ei tee inmisistä syrjäytyneitä tai mukana olevia, vaan sen soveltaminen toimijuutta ja osallisuutta edistävässä tarkoituksessa kuten edellä. Tässä mielessä voitaisiin paremminkin puhua osattomuuden kuiluista ja tietoyhteiskunnan syrjäytyneistä, joille informaatioteknologia toisi selkeää hyötyä yhteiskunnan jäseninä toimimisen sekä oman hyvinvoinnin kannalta, mutta jotka eivät voi tai osaa sitä hyödyntää.

Vuorovaikutteinen teknologia on haastanut yleisöt (toimijat, käyttäjät, kuluttajat) mediatutkimuksen agendallekin aktiivisten yleisöjen ja sosiaalisen toiminnan teorian vauhdittamana. Lisääntyneet mahdollisuudet tietoverkoissa haastavat kehittämään ja tutkimaan osallistuvia viestinnän muotoja, joissa voi "jakaa ja vaihtaa informaatiota sekä kokea ja kehittää toimivia (tietokonevälitteisiä) suhteita"(McQuail 2000, 120; Servaes 2001). Yleisöjen aktiivista toimijuutta tulisi kuitenkin tarkastella erikseen konteksteittain, koska kyseessä ei ole yksi yhtenäinen tapa osallistua (esim. McQuail 2000). 
Peter Dahlgren (2000; 2004) tarjoaa habermasilaisen julkisuuden rakennetta ja poliittista osallistumista korostavan näkemyksen rinnalle käsitettä kansalaiskulttuuri (civic culture) kulttuurintutkimuksellisena lähestymistapana. Silloin nousevat esiin merkityksellisyyden, identiteetin rakentumisen ja sosiaalisen toimijuuden teemat. Tärkeinä elementteinä hän mainitsee yksilöiden ja yhteisöjen relevantit tiedot ja kompetenssit sekä teknologian saatavuus. Hän pitää mediaa ${ }^{1}$ yhtenä kansalaisuuden teknologiana yhdessä hallinnon ja kasvatuksen kanssa. Tässä roolissa media voi palvella kansalaisuutta vahvistavana (empower) tai rajoittavana (disempower) tekijänä.

\section{Kansalaisverkkohankkeissa osallisuutta tietoyhteiskuntaan}

Jarkko Bambergin (2005) mukaan erilaisiin kansalaislähtöistä verkkoviestintää edistäviin hankkeisiin ryhdyttiin vuosituhannen vaihteen molemmin puolin erityisesti kahdesta syystä. Kansalaisten osallistuminen päätöksentekoon oli noussut poliittiseksi kysymykseksi ja informaatioteknologian hyödyntäminen oli kiinnittymässä yhä tiukemmin osaksi yhteiskunnan toimintoja. Tämän myötä kansalaisten osallistuminen ja teknologia nivoutuvat toisiinsa vahvasti juuri julkisen tilan näkökulmasta. Kansalaisen rooli oli rakentunut perinteisesti sivusta seuraajaksi yhteiskunnassa yleensä kuten mediassakin ja tietoverkon ajateltiin olevan uusi mahdollisuuksien tila kansalaislähtöisen viestinnän lisäämiselle (vrt. myös esim. Ridell 2002).

Esa Sirkkunen (2004) luokittelee kolmenlaisten tavoitteiden kansalaisverkkohankkeita: (1) kansalaisen oikeuksia ja palveluja edistämään pyrkivät hankkeet, (2) yhteisöjen ja alueiden kehittämiseen tähtäävät hankkeet sekä (3) kansalaisten osallistumista ja vastavuoroista kansalaiskeskustelua edistävät hankkeet. Yhteistä näissä eri lähestymistavoissa on jollakin tavalla paikallisen osallisuuden ja osallistumisen edistäminen myös sellaisten erityisryhmien piirissä, joiden uhkana on koettu tietoyhteiskuntakehityksestä syrjäytyminen. (Vrt. esim. Uotinen ym. 2001).

Tamperelaisella Mansetorilla[mansetori.uta.fi] ja oululaisella Naapurit.net-sivustolla [kaleva.fi/ naapurit] ovat asukas- ja intressiyhteisöt toteuttaneet verkkomediaa muutaman vuoden ajan. Kehitystyötä on tehty pääosin toimintatutkimus- otteella Tampereen yliopiston Verkkoyhteisöjen kehittyminen -tutkimusprojektissa ${ }^{2}$.

Monitieteiseen tutkimusprojektiin ovat osallistuneet esimerkiksi MIT Media Lab, Tampereen kaupunki, Almamedia, Sanomalehti Kaleva, Oulun Seudun Puhelin ja Teknologian kehittämiskeskus TEKES vuosina 1998-2004. Sen puitteissa on pyritty edistämään erityisesti paikallista verkkojulkisuutta: kansalaisten julkista dialogia muun muassa paikallisten päättäjien kanssa, uusia journalistisia käytäntöjä ja helppokäyttöisiä julkaisutyökaluja. Samantyyppistä kehitystyötä on tehty lähinnä Oppivat Seutukunnat-projektin Netti-Maunulassa (vrt. Karinen ym. 2004). Kansalaisverkkoa ja muita tuki- ja innostamistoimia "teknologian sosiaaliseksi muokkaamiseksi" inmisten arkeen on toteutettu myös Itä-Suomessa esimerkiksi Oppiva Ylä-Karjala- hankkeessa (esim. Uotinen ym. 2001).

Käsittelemme näissä projekteissa vakiintuneita sivustoja kansalaisten verkkomediana eli kansalaisverkkona (civic web). Toiminta on kokonaisuutena verrattavissa monin paikoin yhteisöradioon tai -televisioon, kun paikalliseen julkisuuteen pyritään saattamaan vaihtoehtoista kansalaisnäkökulmaa pääosin vapaaehtoisin voimin. Verkossa ja fyysisissä tapaamisissa nämä julkaisijayhteisöt eli esimerkiksi asukasyhteisöjen nettitiimit muodostavat keskenään verkoston (vrt. Jankowski, van Selm \& Hollander 2000). Toiminnan juuret ovat monin paikoin myös kansalaisjournalismissa, josta on verkkohankkeissa jalostunut kansanjournalismia. Ari Martikaisen (2004, 93-94) mukaan kansalaisjournalismi tuo kyllä lukijan ääntä kuuluviin valtamediassa, mutta se, mitä julkisuuteen asti pääsee on edelleen ammattijournalistin hallussa, kun hän valitsee ja muokkaa tekstiä. Kansanjournalismissa ei tällaista portinvartijaa ole, vaan ihmiset työstävät jutut alusta julkisuuteen saakka sellaisinaan. Tällöin voidaan puhua myös kansalaislähtöisestä tai vaihtoehtomediasta verkossakin (vrt. Kurki 2000; Rodriquez 2001).

Niklas Vainio (2004) puhuu samasta ilmiöstä Internetissä sosiaalisena ohjelmistona (social software), joiden tavoitteina on "edistää ihmisten välistä kommunikaatiota, verkostoitumista ja yhteisöjen syntyä". Vainio erottelee näitä ohjelmistoja kolmeen ryhmään muun muassa käyttäjille tarjoutuvan roolin mukaan. (1) Verkkolokit eli weblogit tuottavat yhteisöllisyyttä keskustelun ja kommentoinnin kautta. Julkiset lokit ovat 
usein yhteisöjen julkaisemia tiettyä aihepiiriä, esimerkiksi uutisia käsitteleviä sivustoja. Yksityiset lokit ovat yksityisen henkilön ylläpitämiä ja niitä on useita lajeja: keskeistä niissäkin on keskustelevuus julkisesti. (2) Wikien eli käyttäjien muokkaamien sivustojen idea on tuottaa tietoa yhdessä eikä vain kommentoida: kuka tahansa sivuston käyttäjä voi lisätä tai poistaa tietoja ilman tunnusta, salasanaa tai kenenkään tarkistusta. (3) Yhteisöportaalissa yhteisöllisyys rakentuu pääasiassa keskustelupalstojen ja kommentointimahdollisuuksien kautta, ja sivuston takana on yhteisö tai organisaatio. Portaali tarjoaa käyttäjille tietoa ja palveluita, joita on tuottamassa kokonaisuutta edustava ydinjoukko, jolla on muokkaamiseen tarvitaan käyttöoikeudet (mt., 140-142).

Keskeistä Vainion (2004) jaottelussa on sosiaalisen ohjelmiston (käytetään myös termiä sosiaalinen media) myötä käyttäjälle avautuva verkkojulkisuus, mikä tekee nämä ohjelmistot kiinnostavaksi juuri digitaalisen toimijuuden ja sen kehittymisen näkökulmasta (vrt. myös esim. Ampuja 2006). Hän luokittelee Mansetorin tutkimusja kehitysprojektin päättyessä vuonna 2004 perinteiseksi yhteisöportaaliksi, jonka osana korttelikirjeenvaihtajien tuottama Mansemedia on varsin lähellä verkkolokia. Tärkeätä sivuston muokkauksessa on "helppotäyttöisyys" eli helppo päivitettävyys, koska mukana on erilaisia digitaalisia taitoja omaavia kansalaistoimijoita (Vainio 2004, 144). Tällä hetkellä moni perinteinen yhteisöportaali rakentuukin järjestelmänä niin sanotuiksi hybrideiksi, joissa hyödynnetään sosiaalisten ohjelmistojen eri mahdollisuuksia.

Tamperelaisella Mansetorilla kaupunkilaiset ja yhteisöt voivat julkaista edelleen näkemyksiään, tarinoitaan tai osallistua keskusteluihin. Mansetori on jatkanut elämäänsä yhteisön jäsenten ylläpitämänä ja muutamien yhteistyötahojen, kuten kaupungin ja yliopiston tukemana. Yhteisöportaali sisältää muun muassa 23 kaupunginosan sivustoa, romanien sivut, 20 kirjeenvaihtajaa eri kaupunginosista sekä vaihtelevan määrän aktiivisia kaupunkilaisia, jotka osallistuvat sivuilla julkaisemiseen, keskusteluihin tai muulla tavoin. Osallistujille järjestetään maksutonta koulutusta verkkosivujen tekemiseksi ja toimintaa aktivoivia tilaisuuksia. Oulussa kaupunginosien yhteystietoja löytyy vuonna 2006 kaupungin lähidemokratiasivuilta, mutta tutkimusprojektin aikana rakentuneella Naapurit.net-sivustolla toi- minta on hiljentynyt. Osa mukana olleista asukasyhdistyksistä on sittemmin toteuttanut omat sivut omalla verkko-osoitteella. Lisäksi paikallinen osuuskunta on ryhtynyt rakentamaan kaupunginosille julkaisutilaa verkkoon.

\section{Digitaalisen toimijuuden edellytyksistä}

Suomi esitellään usein tietoyhteiskuntakeskusteluissa mallimaana, jossa myös kansalaisten tietoyhteiskuntavalmiudet ovat maailman huippuluokkaa. Tietoyhteiskuntavalmiudet liitetään tällöin kansalaisten mahdollisuuksiin käyttää viestintäteknologiaa, kuten Internetiä sekä valmiuksiin käyttää erilaisia uuden teknologian asiointi - ja kuluttajapalveluita. Jos puolestaan halutaan edistää kansalaisten valmiuksia toimijan roolissa, valmiudet on laajennettava kyvyiksi hyödyntää uusia välineitä sekä toimintatapoja itsenäisen elämän hallinnassa sekä yhteisiin asioihin vaikuttamisessa ja osallistumisessa.

Yhteisöllisissä verkkohankkeissa on usein huomattu, että yleisimmät pääsyn ja osallistumisen esteet liittyvät liian vaikeaan tekniikkaan. Yhteisöjen jäsenten kommenteista välittyy runsaasti kriittisiä viestejä niin teknisten laitteiden kuin ohjelmistojen suunnittelijoille. (Sirkkunen ym. 2004; Rantanen 2003, 108-109) Tekniset vaikeudet turhauttavat ja pahimmillaan estävät osallistumisen kuten Mansetorin ja Naapurit. netin toiminnassa mukana olleet asukkaat kuvaavat:

".....Hallitsinkin ohjelman sitten jotenkuten niin sanottujen mummopolkujen avulla. Toimintavirheitäni en paljon pohtinut, vaan pyysin julkaisijan korjaamaan ne jutun lähettäessäni. Kun järjestelmä alkoi reistailla, halukkuuteni julkaisemiseen väheni....."

(Sillanpää 2004)

Vastaanottavat eli tekniset viestintävalmiudet ovat esimerkiksi tietoteknisiä käyttötaitoja ja asiointitaitoja, mutta toimijuuteen ja vuorovaikutukseen vaaditaan lisäksi verkosto - ja viestintätaitoja sekä osallistumisen ja vaikuttamisen taitoja. Media- ja viestintätaidoillakin on siis eri tasoja: vastaanottavan taidon omaava henkilö ymmärtää ja tulkitsee mediasisältöjä, mutta sen lisäksi toiminnallisesti kompetentti viestintätaitoinen voi esimerkiksi toteuttaa mediaesityksiä, 
kommunikoida vuorovaikutteisissa verkostoissa ja hyödyntää verkostoja päämääriensä saavuttamiseksi (Mäkinen 2006; vrt. Viherä 1999).

Tutkimusprojektissa on pyritty kohti emansipatorista viestintäkompetenssia, kun tavoitteena on ollut aktiivinen asukas ja yhteisö, jotka eivät ole ainoastaan kriittisiä median kuluttajia ja tietoyhteiskuntakehitykseen sopeutujia, vaan myös valmiita toimimaan vaihtoehtoisin tavoin uudistajina. Kriittisyys ja tiedostaminen eivät tässä yhteydessä merkitse välttämättä vallitsevien asiantilojen vastustamista tai pelkästään reflektoivaa ajattelua, vaan paikallisiin yhteisiin asioihin tarttumista ja niiden muuttamista verkkoteknologiaa ja -julkisuutta hyödyntämällä (Kotilainen 2004; vrt. Freire 2001).

Mutta emansipatorinen kompetenssikaan ei vielä riitä digitaalisen toimijuuteen kokeiluja pitemmälle, ellei mukaan saada myös päättäjiä, jotka ottavat vaikutusyritykset tosissaan. Yksi selitys päättäjien osallistumattomuuteen verkossa saattaa ainakin osittain löytyä kuntien tiukentuneesta tulosjohtamiskulttuurista (vrt. esim. Lumijärvi \& Jylhäsaari 1999). Mutta vaikka kansalaislähtöisiä pyrkimyksiä olisikin, tulee verkkovuorovaikutuksen sovittamisen pulma julkisen sektorin arkikäytäntöihin esiin lähes kaikissa empiirisissä tutkimuksissa ja kokeiluissa, olipa kyseessä sitten koulu tai tekninen virasto. Syiksi teknologian hyödyntämishaluttomuuteen on esitetty muun muassa ajan riittämättömyyttä ja arkuutta ryhtyä tekstipohjaiseen julkiseen viestintään asukkaiden kanssa uudessa välineessä. (ks. esim. Sirkkunen \& Kotilainen 2004; Häyhtiö \& Keskinen 2005). Ehkä nykyisen päättäjäsukupolven laajemmin vaihtuessa nämä uudet osallistumisen tavat muodostuvat vakiintuneiksi käytännöiksi, kuten on ajan myötä käynyt myös aikanaan radikaaleina pidetyille aktivistitoimille kuten boikotit, vetoomukset ja mielenosoitukset (Ylä-Anttila 2005).

Kaikista kansalaisistakaan ei tule poliittisia vaikuttajia, mutta tällaisilla osallisuushankkeilla voi olla henkilökohtaisesti voimaannuttava merkitys: tuki voi vaikka suunnata ammattiuraa tai vapaa-ajan aktiviteetteja. Esimerkiksi Markku Henneken (2001) kuvaa, miten kansalaisverkkohanke Pohjois-Karjalassa tuki hänen pienyritystoimintaansa verkon kautta globaaleille markkinoille: tärkeiksi osoittautuivat tekniset laitteet ja omat verkkosivun rakentamisen taidot. Lisäksi hän huomauttaa, että verkko toimi hyvin mui- den markkinointitoimien rinnalla, mutta se ei korvannut esimerkiksi kansainvälisillä messuilla käyntiä. Sen sijaan kansalaisena osallistumista hän ei usko verkon liiemmin edistävän:

"... ei se [verkon uutuus] selitä tätä passiivisuutta kuin osittain. Ihmisiä ei yksinkertaisesti tunnu kiinnostavan virtuaalis-poliittinen toiminta sen enempää kuin "reaalinenkaan", minkä on voinut havaita muun muassa siten, että keskusteluihin osallistuneet ovat pitkälti jo muutenkin politiikkaan "sekaantuneita" veteraaneja.”(Henneken 2001)

Hankaluutena hankkeissa ovat olleet myös projektivastaavien tiheä vaihtuvuus ja vapaaehtoistyön pulmat: esimerkiksi puute riittävästä määrästä halukkaita päivittämään verkkosivuja. Suurimmaksi syyksi on havaittu varsinkin perheellisten kohdalla löytää aikaa ylimääräisille harrastuksille. Tämä havainto kertoo myös siitä, että aikaa ja haluja on enimmäkseen niitä, joilla ei ole töitä tai perhettä: esimerkiksi Tesoman asukasraadin aktiivisimmat henkilöt projektissa olivat eläkeläisiä (Heikkilä ja Lehtonen 2004).

"Merkittävintä sivustomme kannalta on ollut ilmaisen palvelintilan ja tietokoneen saaminen kaupunginosamme käyttöön.... Emme ole saaneet kaipaamaamme tukea myöskään kaupunginosan yhdistyksiltä tai järjestöiltä. Toiminnalta puuttuvat toimiva tukiverkko ja sitoutuneet tekijät."(Mäkelä ja Härkönen 2004) "...Ehkä on hyvä palata lähtöruutuun ja tehdä uusi konkreettinen, yhdessä laadittu toimintamalli hyvien projektikokemusten pohjalta." (Salokannel 2004)

Juuri näin Oulun Raksilassa sitten tehtiinkin, kun Naapurit.net-projekti päättyi vuonna 2004. Asukasyhdistyksessä rakentuivat yhteisvoimin omat sivut omaan verkko-osoitteeseen eli domainiin www.raksila.fi.

Tutkimusprojektin aikana verkosta on tullut asukkaille julkaisukanava ja vaikuttamisen väline esimerkiksi kaupungiosien ja intressiryhmien kotisivujen ja kaupunginosakirjeenvaihtajien toiminnan kautta: projekti on siis lisännyt digitaalisen toimijuuden edellytyksiä. Valtamedialle vaihtoehtoisia kansalaislajityyppejä ja muita uusia osallistumisen muotoja on toteutettu verkkoon: ohjelmistoja ja kerronnan muotoja tueksi 
kansalaisten pääsylle entistä helpommin julkiseen vuorovaikutukseen esimerkiksi paikallisten viranomaisten kanssa. Uusiin käytäntöihin kuuluu myös kaupunginosakirjeenvaihtajien toiminta. Tampereella romanien yhteisössä digitaalinen toimijuus näyttäytyy muun muassa palstalla, jossa romanit vastaavat kulttuuriaan koskeviin kysymyksiin ja synnyttävät näin uudentyyppistä vuorovaikutusta valtaväestön kanssa (Sirkkunen \& Kotilainen 2004; Mäkinen 2006).

Kansalaisten toimijuuden kannalta on olennaista käsitellä valmiuksia osallistumisen, osallisuuden ja vaikuttamisen alueilla. Osallisuus kuvaa ihmisten kiinnittymistä yhteisöönsä, jolloin he kokevat olevansa täysivaltaisia yhteisön jäseniä, jolla on mahdollisuus olla mukana yhteisten asioiden suunnittelu- ja päätöksentekoprosesseissa. Yhteisöllisyys ja yhteisöllinen toiminta ovatkin konkreettinen keino lisätä kansalaisten osallisuutta niin yhteenkuuluvuuden kuin vaikuttavana subjektina toimimisen merkityksissä (esim. Freire 2001).

"Parasta oli se alkuvuosien innostus, jolloin porukalla teimme ensimmäiset www-sivustot. Asukkaita tarttui mukaan ... ja pientä verkkovuorovaikutustakin syntyi yhteisön sisällä. Asukasyhdistyksen toiminnalle tärkeä merkitys oli ja on edelleen nopea tiedottamisen lisäarvo."(Salokannel 2004)

Alusta lähtien Oulun Naapurit- projektissa mukana ollut asukasyhdistysaktiivi Lea Salokannel kertoo haastattelussa loppukeväällä2006, että projektista oli hyötyä, koska se antoi rohkeutta itsenäiseen tekemiseen yhteisössä.

Digitaalisen toimijuuden toteuttaminen hankkeissa on voimistanut yhteisöjä eri tavoin. Esimerkiksi Oulussa Kaukovainion asuinalueella ryhdyttiin miettimään aluekuvan kirkastamista, kun tutkimusprojektissa rakentui kokeiluna nuorten näkökulmia asuinalueesta Sanomalehti Kalevan verkkosivuille kommentoitaviksi. Yhteensä 28 nuoren ottamat kännykkäkuvat tekstin kera olivat kommentoitavina määräajan myös alueen asukastuvalla (ks. lisää Kumara 2004):

"Asukastuvan tietotyötorin pc-koneita muutenkin käyttävät koulu- ja työikäiset asiakkaat antoivat kommenttinsa suoraan projektin sivustolle. Vanhemmat asiakkaat katsoivat kuvat videotykillä heijastettuina ja ottivat niihin värikkäästi kantaa. Esimerkiksi ryhmä iäk- käämpiä (70+) rouvia alkoi seurata aktiivisesti tiettyjä kuvia ja niistä heitettyjä huomautuksia."

(Heikkilä 2004)

\section{Digitaalinen voimistuminen etenee spiraalin tavoin}

Yhteisöllisissä verkkojulkaisuhankkeissa on usein leimallista yksilöiden oppimiseen sekä sosiaalisiin verkostoihin liittyvät muutokset. Muutosprosesseja voidaan kuvata spiraalimaisella mallilla, joka käynnistyy keskiön edellytyksistä tiedollisten ja taidollisten valmiuksien parantumisen kautta yhteisön ja yksilön osallistuvaa toimijuutta sekä hyvinvointia lisääviksi seurauksiksi.

Tämä digitaalisen voimistumisen (digital empowerment) spiraalimalli kuvaa muutoksia käynnistävien tekijöiden tärkeyttä sekä muutosten aikaansaamaa liikettä ja kehitystä. Se voi pyörähtää käyntiin ulkopuolisen voiman, kuten projektin ansiosta, joka tarjoaa käynnistymisen edellytyksiä kuten laitteita, koulutuksia ja tukea, mutta kehityksen liikkeessä pitäminen riippuu kuitenkin yhteisöstä ja yksilöistä itsestään (Mäkinen 2006).

Empowerment -käsite on hankalasti suomennettava, ja sitä on käännetty muun muassa voimaantumiseksi, vahvistumiseksi, valtautumiseksi ja väkevöitymiseksi. Tässäkäytetään suomennosta voimistuminen, joka merkitsee laaja-alaista empowerment-as-enablement-tyyppistä mahdollisuuksia luovaa kehitystä. Käsite sisältää sekä yksilöllistä kasvua ja kompetenssin lisääntymistä että osallistumiseen liittyvää toimintakykyisemmäksi kansalaiseksi kehittymistä (vrt. Antikainen 1996, 253; Fetterman 2001, 13). Voimistuminen ei siis ole ensisijaisesti valtamuutosta suhteessa auktoriteetteihin (empowerment-byauthorization), koska monesti valta sinänsä ei ole tavoiteltava päämäärä, vaan tavoiteltavampaa voi olla mahdollisuus parempaan tiedonhankintaan, terveyteen, taitoihin, koulutukseen tai yhteisiin asioihin osallistumiseen. (Zimmerman 1995, 593; Siitonen \& Robinson 1998)

Digitaalista voimistumista voi luonnehtia oppimisprosessiksi, jossa esimerkiksi yhteisö oppii uudenlaista vuorovaikutusta ja keinoja vaikuttaa yhteisiin asioihin. Se on myös inklusiivinen prosessi, joka voi vahvistaa osallisena toimimisen edellytyksiä. Mallin avulla on mahdollista 
havainnollistaa yhteisöllisten kansalaisverkkohankkeiden vaikutuksia sekä edistää kansalaisten digitaalista toimijuutta tarkastelemalla voimistumiseen vaikuttavien tekijöiden yhteyksiä.

Digitaalisen voimistumisen spiraalin käynnistämiseksi on ensinnä mahdollistettava pääsy verkkojulkisuuteen (spiraalin keskiön edellytykset: tarvittava tekniikka, taidot), mutta yhtä merkittäviä ovat asenteelliset valmiudet (spiraalin keskiössä lisäksi: motivaatio, tietoisuus verkkoviestinnän mahdollisuuksista). Asenteelliset tekijät, kuten tietoisuus ja motivaatio ovat usein teknistä pääsyä merkittävämpi tekijä Internetin käytöstä tai käyttämättä jättämisestä päätettäessä (Katz \& Rice 2002, 67-81; The Pew Internet and American Life Project 2003). Näitä edellytyksiä ja valmiuksia voidaan yhteisöllisen hankkeen kautta kehittää ja tukea esimerkiksi koulutuksilla ja ohjauksella. Digitaalisen voimistumisen osallisuutta tukevan funktion kannalta on tärkeää myös yhteisön jäsenten konstruktiivinen osallistuminen (spiraalin keskiön viimeinen elementti), mikä merkitsee mahdollisuutta osallistua verkkoviestintään vastavuoroisesti ja kollektiivista tietoa tuottaen. Parhaimmillaan tämä merkitsee myös kansalaisten osallistumista teknisten väli- neiden ja sovellusten suunnitteluun.

Mansetorin ja Naapurit.netin yhteisöissä spiraalin ensimmäisen kehän muutoksina on yksilöillä ja yhteisöillä voitu kirjata teknisten taitojen kehittymistä, vuorovaikutteisten verkostojen laajenemista, lisääntynyttä tiedon saantia ja tuottamista sekä uusia toimintatapoja. Näistä puolestaan on saattanut syntyä spiraalin voimistavaa liikettä kompetenssimuutosten, osallistumismuutosten, vaikuttamiseen sekä muuhun elämän hallintaan liittyvien muutosten suuntaan. Vaikka oppiminen ei kuulunut hankkeiden varsinaisiin tavoitteisiin, niihin osallistuneet asukkaat ovat kokeneet ne merkittävinä oppimisprosesseina. Muutosten voimistumiskehälle pääseminen puolestaan on edellyttänyt asukkaille räätälöityjä koulutuksia, teknistä neuvontaa, netin käytön mahdollisuuksia sekä yhteisöllistä oppimista asukasryhmien kesken - siis paljon enemmän kuin pelkän pääsyn tietoverkkoon ja tilan siellä. Kompetenssimuutoksista taas on seurannut entistä parempia osallistumisen valmiuksia, tunne vaikuttamisen mahdollisuudesta sekä parhaimmillaan parempi oman elämän kontrolli kulloisessakin kontekstissa. (Mäkinen 2006; vrt. Sirkkunen \& Kotilainen 2004).

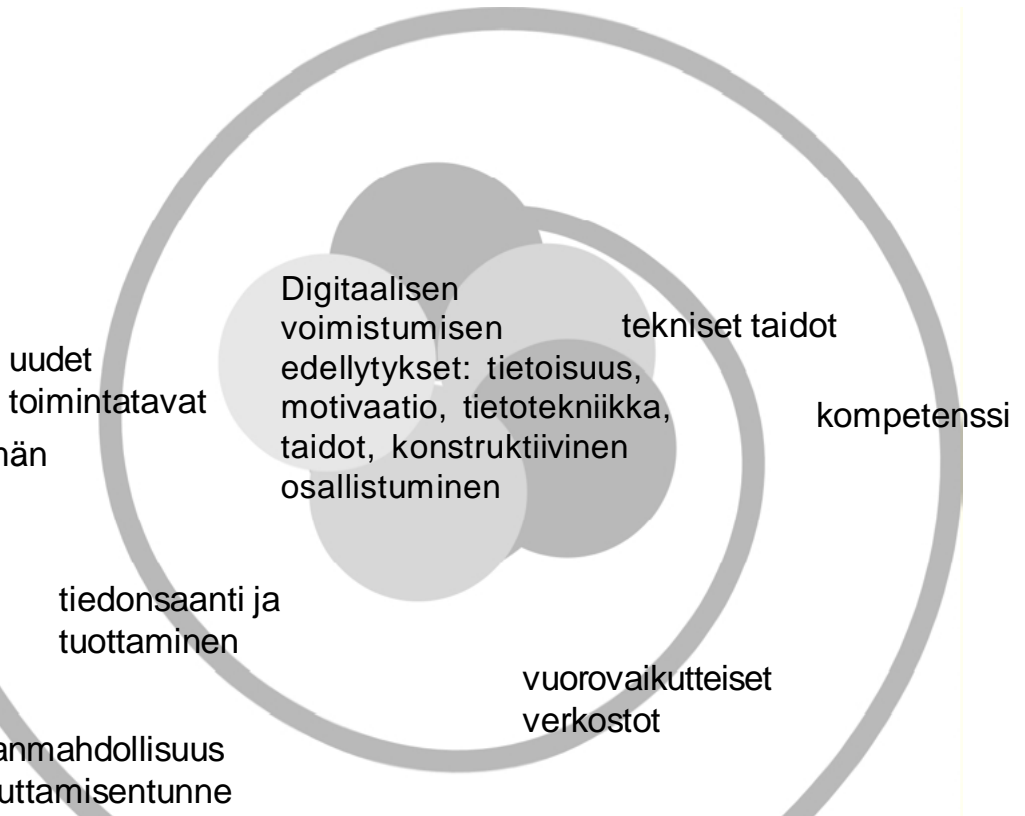

oman elämän kontrolli

Digitaalisen voimistumisen edellytykset: tietoisuus, motivaatio, tietotekniikka, taidot, konstruktiivinen osallistuminen 
Vaikka kansalaisverkkohankkeissa syntynyt toiminta on suhteellisen pienimuotoista, voidaan sanoa niiden synnyttävän digitaalisen voimistumisen kaltaisia muutosprosesseja sekä niistä seuraavaa digitaalista toimijuutta. Kansalaisverkkohankkeissa on voimistumisena ja valtautumisena voitu kirjata tapahtuneen maakunnasta riippumatta myös kokonaan uusia suuntia ja käänteitä elämässä henkilökohtaisella tasolla (vrt. esim. Antikainen 1996). Keskeistä on tällöin ollut erilaisten taitojen oppimisen rinnalla henkiIön oma uskallus ja motivaatio erilaisten kynnysten ylittämiseen jopa vaikeuksien kohtaamisen kautta. Tällaisina käänteinä projekteissa mukana olleet kuvaavat muutoksia esimerkiksi työttömästä työlliseksi ja laitakulkijasta elämänsä hallitsijaksi.

"Mansemedian osuus työllistymisessäni on merkittävä. Ensinnäkin se oli yksi askelma onnellisten sattumien sarjassa. Toisaalta sain valmennusta lehtityöhön...Sain palautetta, jota olen pystynyt hyödyntämään uudessa työssäni paikallislehdessä ja jolla olen paikannut pankkimaailmassa vaurioitunutta itsetuntoani." (Kulju 2004)

Pian ylioppilaaksi valmistumisensa jälkeen pohjoiskarjalainen Joni (2001) kuvaa ajautuneensa moniin pulmiin elämäntilanteessaan ja pitkään jatkuneen työttömyyden kautta myös päihdeongelmiin. Uudelleen kiinni elämään hänet nosti työvoimakurssin myötä harjoittelupaikaksi tullut kansalaistalo, jossa Joni löysi jälleen nuoruuden aikaisen kiinnostuksensa tietotekniikkaan, kehittyi siinä ja sai pikkuhiljaa vastuuta myös muiden tutorina:

"...Olen töissä tällä hetkellä poliittisessa liikkeessä tekemässä kotisivuja.... Käyn koulua: luen yliopistossa matematiikkaa ja tietotekniikkaa....Olen varmaan ihan hyvin mukana yhteiskunnassa päällisin puolin."

Spiraalin käynnistäviä tekijöitä eli keskiön edellytyksiä asukkailla on ollut kohtuullisesti ja niitä on projektien tuella lisätty. Edellytyksissä on ollut myös puutteellisuuksia, kuten laitteiden vaikeakäyttöisyys, koulutusten riittämättömyys ja projektin rajallisista resursseista johtuva tuen vähäisyys. Puutokset edellytyksissä ovat siten jarruttaneet spiraalin voimistavaa liikettä (Mäkinen 2006).
Digitaalisen voimistumisen tasot siis vaikuttavat toinen toisiinsa. Mitä enemmän asukkailla on ollut hallussaan voimistumisen edellytyksiä (tietoisuus, motivaatio, tekniikka, taidot, osallistumisen mahdollisuudet) ja mitä enemmän hanke on niitä edelleen kehittänyt, sitä enemmän tietoyhteiskunnassa tarvittavaa kompetenssia yksilöille ja yhteisöille on kertynyt. Teknisten haasteiden voittaminen uusia taitoja oppimalla on vaikuttanut motivaatiota ja kompetenssia lisäävästi, mutta liian suuret tekniset vaikeudet taas ovat aiheuttaneet jatkuvia pettymyksiä, vähentäneet motivaatiota ja estäneet muutoskehitystä. Spiraalissa tapahtuu siis paitsi liikettä keskiöstä ulospäin ja yhteisöä jäsenineen kehittäen, niin myös edestakaista liikettä ja tilanteita, jolloin liike pysähtyy. Jos esimerkiksi yhteisöllisessä hankkeessa spiraali käynnistyy tasolta, jossa edellytykset ja valmiudet ovat jo pitkälle kehittyneitä, voimistumisen mahdollisuuksia luova prosessi etenee nopeasti ja usein melko itsenäisesti (Mäkinen 2006).

Jos taas edellytyksiä ei ole olemassa, seuraaville tasoille pääseminen vaatii enemmän resursseja, ulkopuolista tukea ja kehitys voi olla hidasta. Esimerkiksi yhteiskunnallisesti marginaalisissa yhteisöissä, kuten romanien tapauksessa, puutteet taidoissa, teknisessä pääsyssä ja tietoisuudessa jarruttivat muutoskehitystä. Romanit kokivat verkkohankkeessa osallistumisen ja yhteistyöverkostojen laajentumisen tärkeimmiksi asioiksi, jotka hankkeessa edistyivät. Heillä merkittävimmät muutokset spiraalin kehillä liittyvät enemmän oman kulttuuriryhmän näkemysten esittämiseen ja sitä kautta merkitykselliseksi toimijaksi tulemiseen, kun taas kaupunginosayhteisöillä korostuvat viestinnälliset ja tiedottamisen tarpeet.

Digitaalinen osallisuus, osattomuus ja voimistuminen pätevät maanosasta riippumatta. Samankaltaisia tuloksia on rakentunut esimerkiksi brasilialaisessa julkaisuhankkeessa Rio de Janeiron slummeissa, missä asukaskirjeenvaihtajat toimittavat juttuja lähiöistään Viva Favela - verkkolehteen. Asukasyhteisöissä on tapahtunut hankkeen ansiosta voimistumiskehitystä julkisuudessa näkyväksi toimijaksi tulemisen kautta, mutta laajemmat vaikutukset yhteisössä ovat jääneet saavuttamatta, koska asukkailla ei ole tarvittavia edellytyksiä (tekniikkaa, tietoja, taitoja) digitaaliseen voimistumiseen. (Mäkinen 2006) 


\section{Projekti sosiokulttuurisena innostajana}

Digitaalisen voimistumisen elementit ovat kietoutuneet toisiinsa monin eri tavoin eivätkä aina lineaarisesti. Merkitykselliseksi tekijäksi prosessissa on kansalaisverkkohankkeissa noussut esiin osallistuminen eli se, että yksilö on vuorovaikutuksessa yhteisössään ja yhteisö verkostoissa, joissa on rakentunut tukea voimistumiskehitykselle, niin positiivisten kuin negatiivistenkin kokemusten kautta.

Kehittämisen näkökulmasta kyse on ollut sosiokulttuurisesta innostamisesta, jonka tavoitteena on rajoittaa syrjäytymiskehitystä ja tukea yksilöiden ja yhteisöjen muutosta elämänsä ja kansalaisuutensa tiedostavaan rakentamiseen. Taustalla on Paulo Freiren vapautuksen pedagogiikka, jonka mukaan yksilö oppii yhteisöllisessä osallistumisessa toiminnan avulla. Prosessissa tärkeitä ovat erilaiset toiminnan innostajat ja itse yhteisö. Sosiokulttuurisessa innostamisessa on mukana aina myös jokin organisaatio toteutuksen mahdollistavana julkisena rakenteena (Kurki 2000; Freire 1973; Freire 2001). Esimerkiksi Verkkoyhteisöjen kehittyminen -tutkimusprojekti Tampereella ja Oulussa on toiminut tällaisena taustarakenteena.

Toiminta on kiinnittynyt kriittiseen mediakasvatukseen ja sosiaalipedagogiikkaan, joihon sijoittuvat myös esimerkiksi nuoriso- ja kulttuurityön parissa toteutetut mediapajat. Tästä näkökulmasta kansalaisten verkkomedian kehittämisessä korostuu sen perusehtona ymmärrys toiminnasta yhteisöllisenä ja dialogisena oppimisena juuri freireläisessä hengessä: tärkeää on herättely tiedostamaan esimerkiksi yhteisön tilanne, toimia ja kriittisesti pohtia vaikkapa uusia tarpeita yhteisön verkkoprojektissa (esim. Kotilainen 2004; Giroux \& McLaren 2001; Freire 1973).

Merkittävä innostajan rooli on ollut yhteisöjen aktiiveilla ja tässä tapauksessa myös tutkimusprojektin tutkijoiden ja mikrotukihenkilöiden tuella. Yksilöiden ja yhteisöjen herättely verkkojulkisuuden ymmärtämiseen ja omien tarpeidensa erittelyyn on rakentunut useissa osaprojekteissa tutkijoiden motivoinnin avulla suunnitteluvaiheessa ja verkkotoiminnassa. Tärkeää on ollut myös vertaiskritiikki ja pohdinta tutkijoiden kanssa toiminnan jälkeen. (esim. Lehtonen 2005; vrt. Kurki 2000, 134-137; Freire 2001).
Kannustava tuki ja osallistuminen ovat lisänneet myös motivaatiota ja sitoutumista. Esimerkiksi kaupunginosakirjeenvaihtaja-projektissa on Ari Martikaisen mukaan (2004) asukkaat ovat pitäneet tärkeinä varsinkin toistensa juttujen kommentointia ja yhteispohdintoja kokoontumisisissa. Tässä osaprojektissa on ollut mukana tusinan verran verkkojuttujen tekijöitä Tampereen eri kaupunginosista. He ovat tehneet vapaaehtoista toimitustyötä omalta asuinalueeltaan: kuvanneet, kirjoittaneet, editoineet juttuja ja vieneet ne julkaisujärjestelmään ja sitä kautta Mansetorin verkkolehden Mansemedian sivuille. Tekijät ovat olleet kiinteässä vuorovaikutuksessa myös juttujensa kohteisiin omalla asuinalueellaan, ja reflektointia on tapahtunut myös suhteessa muihin asukkaisiin yli kirjeenvaihtajaryhmän.

Alkuvaiheessa tutkijat suunnittelivat ja tuottivat asukkaiden verkkotiimien kanssa yhteisöjen ensimmäiset sivustot. Tämän jälkeen tutkijoiden roolia minimoitiin pikku hiljaa. Keväästä 2004 projektin päättymisen jälkeen Tampereella on yhteisöille tarjolla yliopiston puolesta palvelintilaa, teknistä laitteistoa lainaksi ja kaupungin tuella mikrotukea sähköpostitse ja koulutustilaisuuksia verkkojulkaisemisesta. Koordinaattori järjestää myös entisten yksittäisten nettitiimitapaamisten sijasta kuukausittaisen kaikkien tiimien yhteisen verkostotapaamisen.

Dialogisen oppimisen malli ei kuitenkaan ole toteutunut kaikissa osaprojekteissa reflektointiin saakka. Joissakin tapauksissa verkkotoiminta on jäänyt kokonaan kehittämättä yhteisöjen omista tarpeista käsin. Näissä tapauksissa verkkojulkaiseminen on toteutunut vain kokeiluna eikä verkkoaktiiveja ole saatu riittävästi sitoutumaan toiminnan jatkamiseen projektin päättymisen jälkeen.

Metodologisesta näkökulmasta kansalaisverkkoja edistämään pyrkineet tutkimusprojektit ovat siis olleet toimintatutkimuksia kuten varsinkin tässä pääosin kuvattu Tampereella ja Oulussa toteutunut Verkkoyhteisöjen kehittyminen -projekti. Kullakin tutkijalla on ollut oma tavoitteensa hankkeessaan, esimerkiksi verkkotaitojen auttaminen marginaaliryhmille tai kansalaisten tukeminen aktiivisiksi tuottajiksi tietoyhteiskunnassa (Kotilainen 2004). Myös osatutkimusten ja koko hankkeen prosessi on edennyt tyypillisen toimintatutkimuksen spiraalin tavoin, kuten digitaalinen voimistuminenkin yhteisöissä (vrt. Kemmis \& Wilkinson 1998). Toimintatutkimus 
juurtuu mediatutkimuksen kentällä yhteisömediahankkeisiin kuten koko toiminnan lähtökohtakin osittain: yhtä hyvin radiota ja televisiotakin on pyritty edistämään kansalaisviestinnän välineeksi (vrt. esim. Dubell ym. 1980; Einsiedel 2001).

Kun kehittävässä toiminnassa on ollut mukana myös teknologia eli tässä tapauksessa tietoverkko ohjelmistoineen ja järjestelmineen, voidaan käytetty tutkimusote laajentaa myös osallistuvaan design- ja suunnittelututkimukseen (Kotilainen 2005; Bereiter 2002). Sen juuria löytyy esimerkiksi insinööritieteistä ja taiteen tutkimuksesta, mutta useimmiten kehitystyön lähtökohta on ylhäältä alas eli tuottajalähtöisesti pohditaan sitä, miten käytettävyys vaikkapa digitaalisessa järjestelmässä toteutuu. Käyttäjiä on tällöin otettu mukaan lähinnä testaajina (esim. van Lieshout 2001). Kansalaisverkoissa asukkaita on otettu mukaan suunnitteluun alusta lähtien kuten tapahtui esimerkiksi Mansemedian kirjeenvaihtajien kohdalla uuden julkaisujärjestelmän rakentamisessa. Lisäksi asukkaat ovat olleet suunnittelemassa ja ideoimassa kokonaan uusia ilmaisun tapoja eli lajityyppejä verkkoon (Sirkkunen \& Kotilainen 2004).

\section{Digitaalinen voimistuminen toimintojen rakenteisiin}

Kansalaislähtöistä viestintää ja digitaalista voimistumista edistäneissä hankkeissa on korostunut varsinkin koko yhteisössä koettu tarve ja motivaatio osallistumiselle. Mikäli halutaan lisäksi tuottaa omaehtoista verkkomediaa, vaaditaan verkkoon pääsyn lisäksi erilaisten verkkotyökalujen ja ohjelmistojen saatavuutta, riittävää helppokäyttöisyyttä ja kansalaisviestintään sopivia ilmaisun lajityyppejä sekä tietoa niistä. Tärkeäksi on muodostunut myös infrastruktuuri eli pääsy verkkoon ja tila, kuten asukastupa, projektin huone tai kansalaistalo, jossa on ollut mahdollista rakentua yhteisöllisyyttä ja tukea. Mediapedagogiset tukiresurssit ovat myös osoittautuneet tärkeiksi: kehitystyössä tarvitaan siis yhteisöjen nettitiimejä tai muita verkkoaktiiveja, koulutusta ja neuvontaa, jotka voivat toimia osallisuutta ja motivaatiota lisäävinä digitaalisen voimistumisen edellytyksinä.

Kansalaisverkkohankkeiden tulokset osoittavat myös, että kansalaisten verkkotoiminnassa ja sen edistämisessä on menossa edelleen alkuvai- heen prosessi varsinkin asennetasolla. Vuorovaikutus verkossa koetaan outona eivätkä verkkokeskustelut ole saaneet vauhtia asukkaiden eivätkä päättäjien keskuudessa. Esimerkiksi Mansetorin yhteisöjen muutosprosesseissa kävi ilmi, että voimistuminen on selvempää suhteessa oman elämän hallintaan ja yhteisöjen kompetenssiin kuin suhteessa ylhäältä tulevaan päätöksentekoon. Tämän tyyppiseen vaikuttamiseen liittyviä muutoksia on jarruttanut useimmiten päättäjien osallistumattomuus ja vuorovaikutteisten käytäntöjen puuttuminen. Lisäksi hankkeissa saadut tulokset näkyvät toiminnassa hitaasti eikä välittömiä näkyviä tuloksia voida odottaakaan liian pian. Kuten oululaisessa Raksilassakin projektin voimistava merkitys yhteisölle on ollut nähtävissä vasta nyt vuosien päästä.

Yhteisölliset verkkojulkaisuhankkeet vaikuttavat kuitenkin eri tavoin osallisuutta ja toimijuutta edistäen, esimerkiksi yhteisön jäsenten sosiaalisia verkostoja laajentaen, heidän omien näkemystensä ilmaisumahdollisuuksia parantaen ja lisäten yhteisön kompetenssia toimia tietoyhteiskunnassa. Niinpä tämän tyyppisiä hankkeita voidaan pitää onnistuneina toimintamuotoina kansalaisten subjekteina toimimisen lisäämiseksi. Muutokset ovat kuitenkin koskettaneet erityisesti hankkeisiin osallistuneita, joten merkitys koko yhteisölle on jäänyt melko vähäiseksi.

Kun tavoitteena on toimiva demokratia, on sen edellytyksenä myös toimiva kansalaisyhteiskunta, jossa kansalaisilla on rohkeutta ja taitoja osallistua sekä päättäjillä halua kuulla heitä. Yhteiskuntien kansainvälistyminen ja teknologinen muutosvauhti edellyttääkin kansalaisvaikuttamisen uusien tapojen etsimistä ja avointa, kokeilevaa asennetta kuten esimerkiksi Mansetorin tapauksessa on ollut. Kansalaisverkkohankkeet sekä monenlainen kansalaisten aktiivisuus verkossa osoittavat, että uudenlaista kansalaisten julkisuutta ja innovatiivisuutta on syntymässä, mutta nämä resurssit ovat suurelta osin käyttämättömiä tietoyhteiskunnan kehittämisen kannalta. Tällä hetkellä kaivattaisiin enemmän yhteistoiminnallisia malleja ja kollektiivisia toimintatapoja, joissa kansalaiset olisivat suunnittelemassa ja toteuttamassa yhteistyökumppaneina pelkästään informaation vastaanottamisen sijaan. Edelleen siis tarvittaisiin kokeilevaa ja toimintoja kehittävää design- ja toimintatutkimusta yhdessä asukkaiden ja varsinkin syrjäytymiskehityksessä olevien erityisryhmien kanssa. Myös 
toteutuneiden verkkohankkeiden seuranta olisi tärkeää.

\section{Lähteet}

Ampuja, Marko (2006). Blogosfäärien lupaukset ja julkisuuden rakennemuutos. Kasvatus, 37 (1), 60-66.

Antikainen, Ari (1996). Merkittävät oppimiskokemukset ja valtautuminen. Aikuiskasvatuksen vuosikirja 37. Aikuiskasvatuksen Tutkimusseuraja Kansanvalistusseura. BTJ Kirjastopalvelu Oy.

Bamberg, J. (2005). Internet julkisena toimintatilana. Osallistuvaa verkon käyttöä paikallisessa ympäristökiistassa. Tiedotustutkimus 28 (3), 3-15.

Bereiter, C.. (2002). Design Research for Sustained Innovation. Cognitive Studies, Bulletin of the Japanese Cognitive Science Society. 9(3), 321-327.

Dahlgren, P. (2004). Theory, Boundaries and Political Communication. The Uses of Disparity. European Journal of Communication. 19 (1), 7-18.

Dahlgren, P. (2000). The Internet and the Democratization of Civic Culture. Political Communication 17: 335-340.

Dubell, F., Erasmie, T. \& de Vries, J. (1980). Research for the People-Research by the People. Selected Papers from the International Forum on Participatory Research in Ljubljana, Yugoslavia, 1980. Linköping University, Department of Education. Report LiUPEK-R-70.

Einsiedel, E. F. (2001). Action Research for Development Communications: Theory from Practice. In Richards, M., Thomas, P.N. and Nain, Z. (Eds.) Communication and Development: The Freirean Connection. New Jersey: Hampton Press, 97-106.

Fetterman, D. M. (2001). Foundations of Empowerment Evaluation. London: Thousand Oaks.

Freire, P. (1973). Pedagogy of the Oppressed. New York, The Seabury Press.

Freire, P. (2001). Pedagogy of Freedom. Ethics, democracy and civic courage. New York: Rowman and Littlefield Publishers.

Giroux, H. \& McLaren, P. (2001). Kriittinen me- diapedagogiikka. Suom. Aittola, T. \& Suoranta, J.. Vastapaino.

Heikkilä, H. \& Lehtonen, P. (2004). Sosiaalinen suunnistaminen kansalaistaitona. Julkaisussa Sirkkunen, E. ja Kotilainen, S. (Toim.) (2004). Toimijaksi tietoverkoissa. Raportti kansalaislähtöisen verkkoviestinnän mahdollisuuksista. Journalismin tutkimusyksikkö. Tampereen yliopisto. Tiedotusopin laitos. Julkaisuja B44. s. 243-276.

Heikkilä, J. (2004). Kommentti: Aluemediakokeilu herätti asukkaiden kiinnostuksen. Julkaisussa Sirkkunen, E. ja Kotilainen, S. (Toim.) (2004). Toimijaksi tietoverkoissa. Raportti kansalaislähtöisen verkkoviestinnän mahdollisuuksista. Journalismin tutkimusyksikkö. Tampereen yliopisto. Tiedotusopin laitos. Julkaisuja B44, 168-169.

Helsingin Sanomat 4.6.2006. Monsterista mummojen maskotiksi.

Henneken, M. (2001). Verkossa - ollako vai eikö olla? Julkaisussa Uotinen, J., Tuuva, S., Vehviläinen, M. \& Knuuttila, S. (toim.) Verkkojen kokijat. Paikallista tietoyhteiskuntaa tekemässä. Suomen kansantietouden tutkijain seura, 73-92.

Häyhtiö, T. \& Keskinen, A. (2005) Preconditions of Democratic e-Governance: A Critical Approach. Teoksessa Kasvio, A. ja Anttiroiko, A.-V. (toim.) e-City. Analysing Efforts to Generate Local Dynamism in the City of Tampere. Tampere Univeristy Press, 409448.

Jankowski, NW., van Selm, M. \& Hollander, E. (2000). On Crafting Study of Digital Community Networks: Theoretical and Methodological Considerations. Julkaisussa Loader, N. and Keeble, K. (eds.). Community Informatics - Shaping Computer-Mediated Social Networks. London: Routledge/ Francis Taylor.

Joni (2001) Kansalainen nro 164/ 98. Julkaisussa Uotinen, J., Tuuva, S., Vehviläinen, M. \& Knuuttila, S. (toim.) Verkkojen kokijat. Paikallista tietoyhteiskuntaa tekemässä. Suomen Kansantietouden tutkijain seura, 130148.

Karinen, R., Virtanen, P., Pekkala, H. (2004). Oskun oppivuodet. Oppivat Seutukunnat-hankkeen arvioinnin loppuraportti. [http:// 
www.oskut.net/tutkimus/arviointi_ne.pdf] Viitattu 29.8.2006.

Katz, J. ja Rice, R. (2002). Social Consequences of Internet Use. Access, Involvement, and Interaction. Massachusetts Institute of Technology. Cambridge: The MIT Press

Kemmis, S. ja Wilkinson M. (1998). Participatory Action Research and the Study of Practice. In Bill Atweh, Stephen Kemmis and Patricia Weeks (eds.) Action Research in Practice: Partnership for Social Justice in Education. Lontoo: Routledge, 21-36.

Kotilainen, S. (2005). Learning together: Developing Civic Webs as an Innovation Experiment. Teoksessa Kasvio, A. jaAnttiroiko, A.V. (toim.) e-City. Analysing Efforts to Generate Local Dynamism in the City of Tampere. Tampere Univeristy Press, 449-476.

Kotilainen, S. (2004). Kansalaisten verkkomedia oppimisen yhteisönä. Julkaisussa Sirkkunen, E. ja Kotilainen, S. (Toim.) (2004). Toimijaksi tietoverkoissa. Raporttikansalaislähtöisen verkkoviestinnän mahdollisuuksista. Journalismin tutkimusyksikkö. Tampereen yliopisto. Tiedotusopin laitos. Julkaisuja B44. s. 277-299.

Kulju, P. (2004). Kommentti: Pankista paikallislehteen Mansemedian kautta. Julkaisussa Sirkkunen, E. ja Kotilainen, S. (Toim.) (2004). Toimijaksi tietoverkoissa. Raportti kansalaislähtöisen verkkoviestinnän mahdollisuuksista. Journalismin tutkimusyksikkö. Tampereen yliopisto. Tiedotusopin laitos. Julkaisuja B44, 107-108.

Kumara, I. (2004). Kuvaviestejä Oulun Kaukovainiolta. Teoksessa E. Sirkkunen \& S. Kotilainen (toim.) Toimijaksi tietoverkoissa. Raportti kansalaislähtöisen verkkoviestinnän mahdollisuuksista. Tampereen yliopisto, Journalismin tutkimusyksikön julkaisuja B44, 277-300.

Kurki, L. (2000). Sosiokulttuurinen innostaminen. Vastapaino.

Lehtonen, P. (2005). Paikalliset verkkoyhteisöt sosiaalista pääomaa vahvistamassa. "Se on ollut väline, jossa on omalla kontrollilla saanu mieleisensä tiedon julkisuuteen". Tiedotustutkimus 28 (3), 39-55.

Lieshout van, M. J. (2001). Configuring the digital city of Amsterdam. Social learning in experimentation. New Media \& Society. 3(2), 131-156.

Livingstone, S. \& Bober, M. (2005). UK Children Go Online: Final Report of key project findings. Saatavilla www.muodossa $<$ http://www.children-go-online.net > Viitattu 29.08.2006.

Lumijärvi, I. \& Jylhäsaari, J. (1999). Laatujohtaminen ja julkinen sektori. Laadun ja tuloksen tasapaino johtamishaasteena. Gaudeamus.

Martikainen, A. (2004). Kaupunginosakirjeenvaihtajat: yhdessä tekemällä verkkokirjoittajiksi. Julkaisussa Sirkkunen, E. ja Kotilainen, S. (Toim.) (2004). Toimijaksi tietoverkoissa. Raportti kansalaislähtöisen verkkoviestinnän mahdollisuuksista. Journalismin tutkimusyksikkö. Tampereen yliopisto. Tiedotusopin laitos. Julkaisuja B44. Sivut 93-126.

McQuail, D. (2000). McQuail's Mass Communication Theory. Sage Publications.

Mäkelä, T. \& Härkönen, M. (2004). Kommentti: Toiminnasta on tullut osa arkea. Julkaisussa Sirkkunen, E. ja Kotilainen, S. (Toim.) (2004). Toimijaksi tietoverkoissa. Raportti kansalaislähtöisen verkkoviestinnän mahdollisuuksista. Journalismin tutkimusyksikkö. Tampereen yliopisto. Tiedotusopin laitos. Julkaisuja B44, 80-81.

Mäkinen, M. (2006). Digitaalinen voimistuminen ja kansalaisten osallisuus tietoyhteiskunnassa. Esimerkkejä verkossa julkaisevista paikallisyhteisöistä. Tiedotusopin lisensiaatintutkielma. Tampereen yliopisto.

Mäkinen, M. (2000) Internet yhteisöllisenä mediana. Teoksessa Internet kansalaisviestinnän ja paikallisen julkisuuden tilana. Paikallisuus verkkomediassa - projektin loppuraportti. Tampereen Yliopistopaino Oy, 29-54

Nieminen, H. (2004). Kansalaisvaikuttaminen mediayhteiskunnassa. Puheenvuoro tutkimuksen tarpeista. Teoksessa Borg, S. (toim.) Mahdollisuuksien maa. Kartoitusta ja puheenvuoroja kansalaisvaikuttamisen tutkimuksesta. Oikeusministeriön julkaisuja 2004:10, 118-124.

Nordenstreng, K. \& Wiio, J. (toim.) 2001). Suomenmediamaisema. WSOY.

Olsson, T. \& Sandström, H. \& Dahlgren, P. (2003). An Information Society for everyo- 
ne? Gazette: The International Journal for Communication Studies 65 (4-5), 347-363.

Rantanen, H. (2003). Onnistuiko Nettimaunula? Teoksessa Bäcklund, Pia (toim.) Tietoyhteiskunnan osallistuva kansalainen. Tapaus Nettimaunula. Topnova Oy.

Ridell, S. (2002). The Web as a Space for Local Agency. Communications 27. Berlin: Mouton de Gruyter, 147-169.

Rodriguez, C. (2001). Fissures in the Media Scape. An international Study of Citizens' Media. New Jersey Hampton Press.

Räsänen, P. (2005). Tieto- ja viihdekulutuksen muotoutuminen eri väestöryhmissä. Sosiologia 42 (1), 19-34.

Salokannel, L. (2004). Kommentti: Jatkossa tiiviimpää yhteistoimintaa. Kommentti julkaisussa Sirkkunen, E. ja Kotilainen, S. (Toim.) (2004). Toimijaksi tietoverkoissa. Raportti kansalaislähtöisen verkkoviestinnän mahdollisuuksista. Journalismin tutkimusyksikkö. Tampereen yliopisto. Tiedotusopin laitos. Julkaisuja B44, 89.

Servaes, J. (2001). Participatory Communication Research for Democracy and Social Change. Teoksessa Richards, M., Thomas, P.N. and Nain, Z. (toim.) Communication and Development: The Freirean Connection. New Jersey: Hampton Press.

Siitonen, J. \& Robinson, H. (1998). Empowerment: Links to Teachers' Professional Growth. University of Oulu.

Sillanpää, K. (2004). Kommentti: Tekniikka ei ole este osallistumiselle. Kommentti julkaisussa Sirkkunen, E. ja Kotilainen, S. (Toim.) (2004). Toimijaksi tietoverkoissa. Raportti kansalaislähtöisen verkkoviestinnän mahdollisuuksista. Journalismin tutkimusyksikkö. Tampereen yliopisto. Tiedotusopin laitos. Julkaisuja B44, 145.

Sirkkunen, E. (2004). Johdanto: Kansalaislähtöisyys tietoverkoissa. Julkaisussa Sirkkunen, E. ja Kotilainen, S. (Toim.) (2004). Toimijaksi tietoverkoissa. Raporttikansalaislähtöisen verkkoviestinnän mahdollisuuksista. Journalismin tutkimusyksikkö. Tampereen yliopisto. Tiedotusopin laitos. Julkaisuja B44. Sivut 9-26.

Sirkkunen, E. \& Kotilainen, S. (toim.) (2004). Toimijaksi tietoverkoissa. Raportti kansa- laislähtöisen verkkoviestinnän mahdollisuuksista. Tampereen yliopisto, Journalismin tutkimusyksikön julkaisuja B44.

The Pew Internet and American Life surveys in 1995-2000 and 2003. Verkossa: www.pew internet.org.

Uotinen, J., Tuuva, S., Vehviläinen, M., Knuuttila, S. (Toim.). (2001). Verkkojen kokijat: Paikallista tietoyhteiskuntaa tekemässä. Kultaneito IV. Suomen Kansantietouden Tutkijain Seura.

Vainio, N. (2004). Lähtökohtia yhteisölliseen julkaisemiseen. Julkaisussa Sirkkunen, E. ja Kotilainen, S. (Toim.) (2004). Toimijaksi tietoverkoissa. Raportti kansalaislähtöisen verkkoviestinnän mahdollisuuksista. Journalismin tutkimusyksikkö. Tampereen yliopisto. Tiedotusopin laitos. Julkaisuja B44. Sivut 127-146.

Vehviläinen, M. (2001). Paikallista tietoyhteiskuntaa tekemässä. Julkaisussa Uotinen, J., Tuuva, S., Vehviläinen, M. \& Knuuttila, S. (toim.) Verkkojen kokijat. Paikallista tietoyhteiskuntaa tekemässä. Suomen Kansantietouden Tutkijain Seura, 12-26.

Viherä, M.-L. (1999). Ihminen tietoyhteiskunnassa-kansalaisten viestintävalmiudet kansalaisyhteiskunnan mahdollistajana. Turun Kauppakorkeakoulun julkaisuja A-1:1999.

Ylä-Anttila, T. (2005). Julkisuus ja yhteiskunnalliset liikkeet - kansallisista globaaleiksi? Teoksessa Paasonen, S. (toim.) Aktivismi. Jyväskylän yliopisto, Nykykulttuurin tutkimuskeskuksen julkaisuja 85.

Zimmerman, M.A. (1995) Psychological Empowerment: Issues and Illustrations. American Journal of Community Psychology, 23 (5).

\section{Viite}

Medialla tarkoitetaan tässä joukkoviestimiä, esimerkiksi aikakaus- ja sanomalehdet, audiovisuaaliset viestimet ja kaikkien näiden digitaaliset muodot sekä Internet (ks. esim. Nordenstreng \& Wiio 2001).

Artikkeli saatui toimitukseen 7.6.2006.

Se hyväksyttiin julkaistavaksi 15.8.2006. 